\title{
BIODEGRADATION OF PIRIMIPHOS-METHYL USING TWO TYPES OF MICROORGANISMS ISOLATED FROM FAYOUM GOVERNORATE SOIL
}

\author{
Ekram F. Hashim; Makram, A. M. Sayed, Sannaa A. Haron and Hala A. \\ Metwaly \\ Plant Protection Dept., Fac. of Agric., Cairo Univ., Fayoum Branch, Egypt.
}

ABSTRACT

The results showed that the half-life of the pirimiphos-methyl ranged between 2.1 and 1.57 day in non- sterilized soil under $27^{\circ} \mathrm{C}$ and moisture content 25 and $50 \%$ respectively. Also, at the same temperature degree in sterilized soil the half- life of the pirimiphosmethyl reached about 30.1 and 3.8 day under moisture content 25 and $50 \%$ respectively. The half- life of pirimiphos- methyl soil under $35^{\circ} \mathrm{C}$ was about 2 and 1.8 day in non- sterilized soil for both tested moisture content 25 and $50 \%$ respectively. In sterilized soil, the half-life of the same insecticide under $35^{\circ} \mathrm{C}$ was about 6.01 and 3.5 day for 25 and $50 \%$ moisture content, respectively.

Two strains of microorganisms were isolated from the soil one of them a positive gram bacteria strain and the other is a fungi strain. The breakdown of pirimiphos- methyl through these organisms was investigated in a liquid media. The degradation rate of pirimiphosmethyl was faster after first, second and third day by the fungi than the bacteria strain under $35^{\circ} \mathrm{C}$ incubation temperature. On the other hand the degradation by bacteria was accelerated up to the fourth day of incubation. These effects may be due to the increase of the extracellular esterase activity, which tend to increase from the second day of incubation period. Generally, the degradation of pirimiphos-methyl by the two tested microorganisms was higher under $35^{\circ} \mathrm{C}$ than $27^{\circ} \mathrm{C}$. The glucose consumption by the bacteria strain seemed to be correlated to the increase in the esterase activity up to the third day of incubation period. No significant differences were found between the control and the fungi in its glucose consumption.

\section{Key Words: Biodegradation- pirimiphos - methyl-microorganisms}

\section{INTRODUCTION}

Now thousands of different commercial pesticides are available on the market. At the present time, however, there is a growing consensus that conventional chemical pesticides are by no means the panacea they were once considered to be, and that in many cases their indiscriminate use has created for more problems than it has solved. This realization has come gradually and not without controversy, as the quotation from Laws (1992).

The persistence of pesticides in the environment is one of the important factors that determine their efficacy and their impact on non target species. If pesticides degraded rapidly to harmless substances through natural processes there would be little opportunity for them to spread throughout the food web through feeding relationships, and for their concentrations to increase through biological magnification. The persistence of many pesticides depends on the surrounding environment compartments (soil, water, air, plant and animal). Soil

Fayoum J. Agric. Res. \& Dev., Vol.19, No.2, July, 2005 
Ekram F. Hashem, et al.,

constitute is a major environmental compartment on the persistence and degradation of pesticides.

Martinez Toledo et al (1992) investigated the effect of two selected organophosphorus insecticides pirimiphos-methyl and chlorpyrifos on soil microflora in an agricultural loam decreasing aerobic dinitrogen fixing bacteria and dinitrogen fixation. Racke and Coats (1988a) Racke et al (1990) explained the resistance of chlorpyrifos to enhanced biodegradation in soil. Results indicate that chlorpyrifos is not susceptible to enhanced microbial degradation and repeated chlorpyrifos application should have no effect on its persistence or efficacy. Getzin and Rosefield (1968) showed that all of the pesticides degraded faster in non- sterile soils. Some insecticides decomposed much faster in irradiated soil than in autoclaved soil. Cink and Coats (1993) studied the effect of the soil moisture in the persistence of chloropyrifos. They also found that the temperature did not effect the degradation of chloropyrifos. Aly et al. (1987) studied persistence of aldicarb, chlorpyrifos and methomyl in 3 different types of soil common in Egypt. They found that, degradation of aldicarb was faster in silty clay loam, followed by sand-clay loam and clayloam, while chlorpyrifos degraded fastest in clay- loam, followed by silty-clay loam and sandy-clay-loam. Methomyl degraded fastest in sandy-clay-loam, followed by silty clay loam and clay loam.

This study was carried to determine the persistence of pirimiphos-methyl under sterilize and non-sterilized soil. Moreover, this study aimed to emphasize the role of low tolerant isolates of microorganism on the biodegradation of pirimiphos-methyl in soil under different levels from moisture and temperature.

\section{MATERIALS AND METHODS}

\section{Degradation of pesticides in soil:}

The soil samples were taken from Dar Al-Ramad farm, Faculty of Agriculture, Cairo University, Fayoum branch. Samples of soil, 10g each were placed in glass flasks at a moisture content of 25 or $50 \%$ with distilled water. Each group of samples was divided into two groups, one was left as non sterilized soil and the other was sterilized by using autoclave at $125^{\circ} \mathrm{C}$ for 20 min. The non- sterilized soil was treated with pirimiphos-methyl $50 \% \mathrm{EC}$. at the rate of 40ppm. The sterilized soil was treated with the same concentration under UV sterilized Laminar- flow. Each group of soil samples was divided to two groups, one was incubated at $27^{\circ} \mathrm{C} \pm 2{ }^{\circ} \mathrm{C}$ and the other incubated at $35^{\circ} \mathrm{C} \pm 2^{\circ} \mathrm{C}$. At time intervals of $0,1,2,3,4,5,8,12,18,25$ and 39 days samples were taken for residues analysis.

\section{Extraction and clean up of pirimiphos- methyl from soil}

The insecticide residues were extracted and purified. Fifty gram of soil was taken, and placed in $500 \mathrm{ml}$ flask and shacked with $50 \mathrm{ml}$ distilled water followed by $400 \mathrm{ml}$ of $20 \%$ acetone in $\mathrm{n}$-hexane fore 10 minutes. An equal volume of distilled water was added to the aliquot. A portion of extract was placed in a separating funnel and shaken for one min, allowing the n-hexane and water layer to separate and run off the water layer including any interfacial emulsion. The n-hexane layer was dried by passing though anhydrous sodium sulphate and then evaporate by using a rotary evaporator on a water bath at $40^{\circ} \mathrm{C}$. The residues were redissolved in $2 \mathrm{ml}$ of acetone then transferred to a $5 \mathrm{ml}$

Fayoum J. Agric. Res. \& Dev., Vol.19, No.2, July, 2005 
BIODEGRADATION OF PIRIMIPHOS-METHYL USING TWO........3

vials. After the evaporation of acetone using a light stream of air, the samples were kept under refrigeration until used. The recoveries from control samples fortified with a concentrate of primiphos- methyle for soil was 95\% to $106 \%$

\section{Isolation of pesticides tolerant microorganisms from soil.}

Mineral agar media was prepared and supplied with $0.5 \mathrm{~g} / \mathrm{l}$ glucose as a carbon source. The agar plates were treated with pirimiphos-methyl at a concentration of $40 \mathrm{ppm}$. One gram of soil was added to $250 \mathrm{ml}$ sterilized water and shaken to make a homogeneous suspension, $250 \mu \mathrm{L}$ from the suspension was added at the surface of the agar plate. The inoculated plates were incubated at $27^{\circ} \mathrm{C}$ until the microorganisms are grown. Two isolates were screened and chosen after the inoculation of agar plates from all possible growing microorganisms on the surface of different plates. One was a G.+ organisms, motile, long rods, producing no color, mucoid growth on plates and aerobic in its nature. The other which was found to spread over the surface of most plates, has a mycelia type of growth, produces planets of spores on plates surface, white color, not acceptable to gram stain, aerobic and non motile. It was a type of fungi. The two isolates were used proceedingly as tolerant microorganisms to tested pesticides.

\section{Degradation of pirimiphos-methyl in liquid media}

Mineral liquid media was used to evaluate the biological performance of the isolated soil microorganisms to degrade the pesticide under investigation. Pirimiphos-methyl was added to $100 \mathrm{ml}$ sterilized liquid media in $250 \mathrm{ml}$ Erlenmeyer flasks to final concentration of 40 or $100 \mathrm{ppm}$. The flasks of each concentration were divided into two groups, the first was incubated with microorganisms at $27^{\circ} \mathrm{C}$ and the second was incubated under $35^{\circ} \mathrm{C}$ for $1,2,3,4$ and 7 days. Three replicates were taken at each incubation period as well as untreated samples (control). The $\mathrm{PH}$ value, glucose consumption, total protein in cells and liquid media were determined according to Lowrey et al., (1952) and esterase activity after Gomori (1953). The bacteria inoculum was prepared by growing the organisms on Malik liquid medium for 24 hours at $30^{\circ} \mathrm{C}$ after which the cell counts was measured using the turbidity method described by Ellen (1994) and pesticides residues were determined. Swelam (1996).

\section{HPLC analysis}

The residue analysis of pirimiphos- methyl was determined using HPLC according to Swelam (1996).

\section{RESULTS AND DISCUSSION}

The residue of Pirimiphos- methyl in non-sterilized soil incubation under $27{ }^{\circ} \mathrm{C}$ and $25 \%$ moisture content ranged between $83.3 \pm 2.9 \%$ after the first day of the incubation period and $67 \pm 2.1 \%$ after $18^{\text {th }}$ day. After 25 and 39 days the residue of pirimiphos-methyl could be detected. Under the same temperature and $50 \%$ moisture content, no residue of pirimiphos-methyl was detected from the $12^{\text {th }}$ day. This results may indicate that the moisture content play a role in pirimiphos-methyl degradation in soil. In sterilized soil the residue of pirimiphos-methyl was ranged between $91.7 \pm 2.8$ and $40 \pm 1.5 \%$ after $1^{\text {st }}$ and $39^{\text {th }}$ days, respectively, under $25 \%$ moisture. The residue decreased more under $50 \%$ moisture content where it ranged between $95 \pm 5$ and $4.7 \pm 1.5 \%$ after the first and $39^{\text {th }}$ day, respectively, (Table 1). The thermal effect enhanced the

Fayoum J. Agric. Res. \& Dev., Vol.19, No.2, July, 2005 
degradation of pirimiphos-methyl in the sterilized soil. Also the break down rate of the tested pesticide was faster at $35^{\circ} \mathrm{C}$ after the first three days than at $27^{\circ} \mathrm{C}$, The percent residue of pirimiphos-methyl under $35^{\circ} \mathrm{C}$ and $25 \%$ moisture content was ranged between $75 \pm 13.4$ and $2.33 \pm 58 \%$ after $1^{\text {st }}$ and $25^{\text {th }}$ day incubation in non-sterilized soil. Also under the same degree and 50\% moisture the residue of pirimiphos-methyl proved $65 \pm 8.7$ and $8,2.1 \%$ after the $1^{\text {st }}$ and $8^{\text {th }}$ day, respectively. After the $12^{\text {th }}$ day no pirimiphos-methyl residue could be detected. On the sterilized soil, the residue of the pirimiphos-methyl was detected after the $39^{\text {th }}$ day as $11.3 \pm 1.2$ under $25 \%$ moisture and $8.7 \pm 3.2$ under $50 \%$ moisture (Table 1).

The half-life of pirimiphos-methyl ranged between 2.1 and 1.57 day in non-sterilized soil under $27^{\circ} \mathrm{C}$ and moisture content 25 and $50 \%$ respectively. Also, at the same temperature degree in sterilized soil the half-life of pirimiphos-methyl was about 30.1 and 3.8 day under moisture content i.e. 25 and $50 \%$, respectively. The half-life of pirimiphos-methyl in non-sterilized soil under $35^{\circ} \mathrm{C}$ was about 2 and 1.8 day under both tested moisture content 25 and $50 \%$ respectively. In sterilized soil, the half-life of the tested insecticide under $35^{\circ} \mathrm{C}$ was about 6.02 and 3.5 day for 25 and $50 \%$ moisture content, respectively. These results agreed with those reported by Lichtensten et al. (1964), (1968), Walker and Stojanovic (1973), Getzin and Rosefield (1968) and Naumann (1959).

The physical and chemical properties of the soil such as soil temperature, moisture and $\mathrm{pH}$, the physicochemical properties of the pesticide, and finally span of time during which pesticide remains in contact with the soil, affect the adsorption, desorption and biological activity of pesticides. Our results agree with those of Mulbry et al. (1996).

\section{Effect on the Glucose consumption.}

Results in Table 2 indicate that the bacteria strain under $27^{\circ} \mathrm{C}$ increased the glucose consumption significantly $(\mathrm{P} \leq 0.01)$ in pirimiphos-methyl at a concentration of 40 and 100ppm. In case of the fungi strain (Table 2) results show significant increase in glucose consumption after the $1^{\text {st }}$ day under $35^{\circ} \mathrm{C}$ for both (40 and $100 \mathrm{ppm})$ pirimiphos-methyl. After the $7^{\text {th }}$ day the glucose consumption decreased significantly $(\mathrm{P} \leq 0.01)$. Under $27^{\circ} \mathrm{C}$ the results indicate no significant differences in glucose consumption between the control and treated fungi. 
BIODEGRADATION OF PIRIMIPHOS-METHYL USING TWO........5

Table 1

Fayoum J. Agric. Res. \& Dev., Vol.19, No.2, July, 2005 
Ekram F. Hashem, et al.,

Table (2) The percentage of glucose consumption by the bacteria and fungi strain under $27^{\circ} \mathrm{C}$ and $35^{\circ} \mathrm{C}$ in medium treated with Pirimiphos methyl

\begin{tabular}{|c|c|c|c|c|c|c|c|}
\hline \multirow{2}{*}{ Isolate } & \multirow{2}{*}{$\begin{array}{c}\text { Temperature } \\
{ }^{\circ} \mathrm{C}\end{array}$} & \multirow{2}{*}{$\begin{array}{c}\text { Concentration } \\
(\text { ppm) }\end{array}$} & \multicolumn{5}{|c|}{ Sampling intervals in days } \\
\hline & & & 1 & 2 & 3 & 4 & 7 \\
\hline \multirow{6}{*}{ 总 } & \multirow{3}{*}{27} & $\mathbf{0}$ & $13 \pm 6^{\mathrm{b}}$ & $38.9 \pm 1.6^{\text {cde }}$ & $57.9 \pm .2^{\mathrm{f}}$ & $65.2 \pm .2^{\mathrm{i}}$ & $70.1 \pm .8$ \\
\hline & & 40 & $16.9 \pm 1.8^{\mathrm{bc}}$ & $60.1 \pm .2 \mathrm{~g}$ & $69.1 \pm 1.1^{\mathrm{g}}$ & $72.3 \pm 1.1^{\mathrm{j}}$ & $72 \pm 0$ \\
\hline & & 100 & $6.7 \pm .5^{\mathrm{a}}$ & $28.7 \pm 2.8^{\mathrm{b}}$ & $68.7 \pm 2.1^{\mathrm{g}}$ & $70.7 \pm .5^{\mathrm{j}}$ & $71 \pm 0$ \\
\hline & \multirow{3}{*}{35} & $\mathbf{0}$ & $24.6 \pm 0^{\mathrm{ef}}$ & $39.7 \pm 7.5^{\text {cde }}$ & $48 \pm 3.4^{\mathrm{e}}$ & $46.4 \pm 3.2^{\text {cde }}$ & $47.5 \pm .4$ \\
\hline & & 40 & $16.2 \pm 0^{\mathrm{bc}}$ & $21 \pm 0^{\mathrm{a}}$ & $47.7 \pm 1.5^{\mathrm{de}}$ & $53.6 \pm 1.4^{\mathrm{fgh}}$ & $43.1 \pm 1.1$ \\
\hline & & 100 & $4.5 \pm .1^{\mathrm{a}}$ & $42.6 \pm .3^{\mathrm{e}}$ & $46.1 \pm 2.9^{\mathrm{de}}$ & $42.4 \pm 0^{\mathrm{bc}}$ & $48 \pm 3.4$ \\
\hline \multirow{6}{*}{ 预 } & \multirow{3}{*}{27} & $\mathbf{0}$ & $24.2 \pm .7^{\mathrm{ef}}$ & $37.4 \pm .3^{\text {cde }}$ & $41.7 \pm .3^{\mathrm{cd}}$ & $54.6 \pm 1^{\text {gh }}$ & $58.8 \pm 0$ \\
\hline & & 40 & $39.6 \pm 0^{g}$ & $42.9 \pm .1^{\mathrm{e}}$ & $49 \pm 0^{\mathrm{e}}$ & $58.3 \pm .5^{\mathrm{h}}$ & $52.9 \pm 2.1$ \\
\hline & & 100 & $28.3 \pm 2.8^{\mathrm{f}}$ & $40.4 \pm 3.8 \mathrm{de}$ & $43.9 \pm .1 \mathrm{cde}$ & $48.9 \pm 1.8 \mathrm{def}$ & $52.9 \pm .1$ \\
\hline & \multirow{3}{*}{35} & $\mathbf{0}$ & $7.4 \pm 2.4^{\mathrm{a}}$ & $36.2 \pm 0^{\text {cd }}$ & $39.7 \pm 6.8^{\mathrm{bc}}$ & $50.4 \pm 5.5^{\mathrm{efg}}$ & $42 \pm 0$ \\
\hline & & 40 & $22.5 \pm .9^{\mathrm{de}}$ & $49.9 \pm .1^{\mathrm{f}}$ & $31.2 \pm 1.3^{\mathrm{a}}$ & $44.4 \pm 2.9^{\mathrm{cd}}$ & $53.1 \pm 2.2$ \\
\hline & & 100 & $19.5 \pm .2^{\text {cd }}$ & $39.9 \pm 1.1^{\text {cde }}$ & $44 \pm 5.8^{\text {cde }}$ & $47.3 \pm 8^{\text {cde }}$ & $46.7 \pm 4$ \\
\hline
\end{tabular}

\section{PH monitoring in liquid media}

Generally, it could be suggested that the microorganism type and the temperature are the main factors which play the role in the change of $\mathrm{pH}$ value. Also, the results show that the $\mathrm{pH}$ value of the growth media tend to decrease in presence of the fungi strain more than the bacteria strain under $35^{\circ} \mathrm{C}$ than $27^{\circ} \mathrm{C}$. The pesticides free media (control) show the lowest PH value (Table 3) after the first day as compared to pirimiphos-methyl treated media. This may be due to the weakness state of the microorganisms at the beginning of the incubation with the pesticides under investigation

Table (3): $\mathrm{pH}$ value profile during 7 days incubation of bacteria and fungi strain with different concentrations of pirimiphos methyl under $27^{\circ} \mathrm{C}$ and $35^{\circ} \mathrm{C}$

\begin{tabular}{|c|c|c|c|c|c|c|c|}
\hline \multirow{2}{*}{ Isolate } & \multirow{2}{*}{$\begin{array}{c}\text { Temperature } \\
{ }^{\circ} \mathrm{C}\end{array}$} & \multirow{2}{*}{$\begin{array}{c}\text { Concentration } \\
\text { (PPm) }\end{array}$} & \multicolumn{5}{|c|}{ Sampling intervals in days } \\
\hline & & & 1 & 2 & 3 & 4 & 7 \\
\hline \multirow{6}{*}{ Bacteria } & \multirow{3}{*}{$27^{\circ} \mathrm{C}$} & $0 \mathrm{ppm}$ & $03.85+.06^{\mathrm{c}}$ & $3.55+.02^{\text {cdef }}$ & $3.62+.02^{\mathrm{c}}$ & $3.54+.05^{\text {gh }}$ & $3.63+.01^{\mathrm{ef}}$ \\
\hline & & $40 \mathrm{ppm}$ & $4.52+.1^{\mathrm{a}}$ & $3.58+.07^{\text {cde }}$ & $3.66+.04^{\mathrm{c}}$ & $3.63+.03^{\mathrm{efg}}$ & $3.68+.01^{\mathrm{cde}}$ \\
\hline & & $100 \mathrm{ppm}$ & $4.61+.09^{\mathrm{a}}$ & $4.3+.1^{\mathrm{a}}$ & $3.77+.04^{\mathrm{b}}$ & $3.66+.01$ cdefg & $3.74+.02 \mathrm{bcde}$ \\
\hline & \multirow{3}{*}{$35^{\circ} \mathrm{C}$} & $0 \mathrm{ppm}$ & $3.17+.0^{1 \mathrm{j}}$ & $3.24+.05^{\mathrm{j}}$ & $3.34+.1^{\mathrm{e}}$ & $3.48+.17^{\mathrm{h}}$ & $3.26+.02^{\mathrm{h}}$ \\
\hline & & $40 \mathrm{ppm}$ & $3.62+.02^{\mathrm{de}}$ & $3.29+.01^{\mathrm{ij}}$ & $3.37+.06^{\mathrm{de}}$ & $3.34+.03^{\mathrm{i}}$ & $3.23+.01^{\mathrm{h}}$ \\
\hline & & $100 \mathrm{ppm}$ & $4.07+.03^{\mathrm{b}}$ & $3.39+.02^{\text {ghi }}$ & $3.34+.02^{\mathrm{de}}$ & $3.32+.01^{\mathrm{i}}$ & $3.23+.02^{\mathrm{h}}$ \\
\hline \multirow{6}{*}{ Fungi } & \multirow{3}{*}{$27^{\circ} \mathrm{C}$} & $0 \mathrm{ppm}$ & $3.5+.13^{\mathrm{efg}}$ & $3.43+.04^{\text {fgh }}$ & $3.61+.05^{\mathrm{c}}$ & $3.79+.02^{\mathrm{ab}}$ & $3.78+.04^{\text {abcde }}$ \\
\hline & & $40 \mathrm{ppm}$ & $3.49+.08^{\mathrm{efg}}$ & $3.53+.29^{\text {cdef }}$ & $3.98+.04^{\mathrm{a}}$ & $3.77+.02^{\mathrm{abc}}$ & $3.8+.03^{\text {abcde }}$ \\
\hline & & $100 \mathrm{ppm}$ & $3.67+.03^{\mathrm{d}}$ & $3.61+0^{\text {bcd }}$ & $3.95+.02^{\mathrm{a}}$ & $3.78+.01^{\mathrm{ab}}$ & $3.82+.04^{\text {abcd }}$ \\
\hline & \multirow{3}{*}{$35^{\circ} \mathrm{C}$} & $0 \mathrm{ppm}$ & $3.39+.03^{\mathrm{gh}}$ & $3.48+.17^{\text {efgh }}$ & $3.34+.07^{\mathrm{e}}$ & $3.59+.09^{\mathrm{fgh}}$ & $3.47+.29^{\mathrm{g}}$ \\
\hline & & $40 \mathrm{ppm}$ & $3.32+.01^{\mathrm{hi}}$ & $3.62+.02^{\mathrm{bc}}$ & $3.35+.02^{\mathrm{e}}$ & $3.75+.05^{\mathrm{abcd}}$ & $3.69+.02^{\text {cde }}$ \\
\hline & & $100 \mathrm{ppm}$ & $3.47+.02^{\mathrm{fg}}$ & $3.54+.01^{\text {cdef }}$ & $3.47+.21^{\mathrm{d}}$ & $3.64+.02^{\operatorname{defg}}$ & $3.7+0^{\text {bcde }}$ \\
\hline
\end{tabular}

$\mathrm{A}, \mathrm{b}, \mathrm{c}, \mathrm{d}, \mathrm{e}, \mathrm{f},------m e a n s$ in the same column per each item having different letter are significantly diferent $(\mathrm{P} \leq 0.01)$ Esterase activity.

Fayoum J. Agric. Res. \& Dev., Vol.19, No.2, July, 2005 


\section{BIODEGRADATION OF PIRIMIPHOS-METHYL USING TWO........7}

\section{Protein content:}

The intracellular $(\mathrm{mg} / \mathrm{g})$ protein content of bacteria increased significantly after the $1^{\text {st }}, 2^{\text {nd }}, 4^{\text {th }}$ and $7^{\text {th }}$ days of incubation with 40 and $100 \mathrm{ppm}$ concentration, of primiphos-methyl at $27^{\circ} \mathrm{C}$; At $35^{\circ} \mathrm{C}$ however, the increase was after $1^{\text {st }}$ to seven days with $40 \mathrm{ppm}$ concentration but with $100 \mathrm{ppm}$ this increase was after $2^{\text {nd }}$ to seven days only. The extracellular $(\mathrm{mg} / \mathrm{dl})$ protein contents decreased significantly after $1^{\text {st }}, 3^{\text {rd }} 4^{\text {th }}$ and $7^{\text {th }}$ days of incubation with $40 \mathrm{ppm}$ of pirimiphos-methyl at $27^{\circ} \mathrm{C}$ while at the same temperature with $40 \mathrm{ppm}$ concentration the decrease was after $1^{\text {st }}, 2^{\text {nd }} 3^{\text {rd }}$ and $7^{\text {th }}$ days of incubation . The extracellular $(\mathrm{mg} / \mathrm{dl})$ protein content was increased after $2^{\text {nd }}$ to $7^{\text {th }}$ days of incubation with $40 \mathrm{ppm}$ concentration at $35^{\circ} \mathrm{C}$ while at $100 \mathrm{ppm}$ it increased significantly at the $3^{\text {rd }}, 4^{\text {th }}$ and $7^{\text {th }}$ days. At $35^{\circ} \mathrm{C}$ the increase was significant after $1^{\text {st }}$ to $7^{\text {th }}$ days of incubation with both concentrations. The decrease was significant after $4^{\text {th }}$ and $7^{\text {th }}$ days with both concentration 40 and $100 \mathrm{ppm}$ at $27^{\circ} \mathrm{C}$. The extracellular $(\mathrm{mg} / \mathrm{dl})$ protein content was decreased significantly after $1^{\text {st }}, 2^{\text {nd }}, 3^{\text {rd }}$, and $7^{\text {th }}$ days of incubation with primiphos-methyl concentration $40 \mathrm{ppm}$ at $27^{\circ} \mathrm{C}$ but at $100 \mathrm{ppm}$ there was an increase in the protein content after $1^{\text {st }}, 2^{\text {nd }}, 4^{\text {th }}$, and $7^{\text {th }}$ days. (Table 4).

\section{Esterase activity:}

The extracellular esterase activity was recorded at both incubation temperatures. The esterase activity was increased significantly after $1^{\text {st }}$ day incubation at $27^{\circ} \mathrm{C}$. The maximum activity was $8.86 \pm 2.5 \mathrm{~mm} \mathrm{ol} / \mathrm{h} \mathrm{mg}$ protein after the second day with 40ppm pirimiphos-methyl where the control value was $5.98 \pm 7 \mathrm{mmol} / \mathrm{h} / \mathrm{mg}$ protein. Under incubation temperature $35^{\circ} \mathrm{C}$ and $40 \mathrm{ppm}$ pirimiphos-methyl the esterase activity reached $9.73 \pm .8 \mathrm{mmol} / \mathrm{h} / \mathrm{mg}$ protein against $5.89 \pm .2 \mathrm{mmol} / \mathrm{h} / \mathrm{mg}$ protein for the control (Table 5). The activity of the intracellular esterase was inhibited through the incubation of the bacteria strain with 40 and $100 \mathrm{ppm}$ pirimiphos-methyl under $27^{\circ} \mathrm{C}$. The incubation decreased significantly after the first and seventh day incubation of the bacteria with 40 and 100ppm of pirimiphos-methyl.

The intracellular esterase activity of fungi strain at $27^{\circ} \mathrm{C}$ was decreased at $1^{\text {st }}$ and $2^{\text {nd }}$ day with $40 \mathrm{ppm}$ concentration but showed an increase at $3^{\text {rd }}, 4^{\text {th }}$ and $7^{\text {th }}$ days. With $100 \mathrm{ppm}$ concentration the activity decreased at $1^{\text {st }}, 2^{\text {nd }}, 3^{\text {rd }}$ and $4^{\text {th }}$ days but increased in $7^{\text {th }}$ day. The extracellular esterase activity was increased at $1^{\text {st }}, 2^{\text {nd }}, 3^{\text {rd }}$ and $7^{\text {th }}$ days with $40 \mathrm{ppm}$ concentration at $27^{\circ} \mathrm{C}$ and decreased at the $4^{\text {th }}$ day. The extracellular esterase activity decreased at $1^{\text {st }}, 2^{\text {nd }}, 4^{\text {th }}$ and $7^{\text {th }}$ days, but increased at $3^{\text {rd }}$ day at the same conditions but with $100 \mathrm{ppm}$.

\section{Pirimipos-methyl biodegradation in liquid media:}

The residue of $40 \mathrm{ppm}$ pirimipos-methyl in control (without microorganism was ranged from $49.6 \pm 1 \%$ after one day to $6.6 \pm 8 \%$, when incubated under $27^{\circ} \mathrm{C}$. The determined residue after 7 days when incubated at $35^{\circ} \mathrm{C}$ ranged from $50.3 \pm 1.3 \%$ after one day to $20.7 \pm 1 \%$ after seven days incubation. Table 6 shows the same trend in case of the higher concentration 100ppm. Walker and Stojanovic (1973) found that malathion disappeared from natural soil more rapidly than from soil sterilized by a number of techniques, Getzin (1968) found that degradation rates for diazinon were similar in autoclaved and nonautoclaved soil, while Zinophos degraded faster in non -autoclaved soil than in autoclaved soil. They also stated that parathion persisted longer in autoclaved soil than in non-autoclaved soil.

Fayoum J. Agric. Res. \& Dev., Vol.19, No.2, July, 2005 
Ekram F. Hashem, et al.,

Table 4

Fayoum J. Agric. Res. \& Dev., Vol.19, No.2, July, 2005 
BIODEGRADATION OF PIRIMIPHOS-METHYL USING TWO........9

Table (5) Residue percenet of Primiphos-methyl and Aldicarb in Liquide media incubated with bacteria and fungi under $27^{\circ} \mathrm{C}$ and $35^{\circ} \mathrm{C}$

\begin{tabular}{|c|c|c|c|c|c|c|c|}
\hline \multirow{2}{*}{ Isolate } & \multirow{2}{*}{ 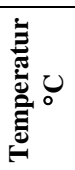 } & \multirow{2}{*}{ 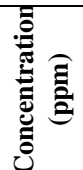 } & \multicolumn{5}{|c|}{ Ssmpling intervals in days } \\
\hline & & & 1 & 2 & 3 & 4 & 7 \\
\hline \multirow{4}{*}{ 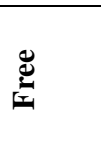 } & \multirow[t]{2}{*}{27} & 40 & $49.6 \pm 1$ & $40 \pm 1.9$ & $39 \pm 1.5$ & $25.9 \pm 1.2$ & $6.6 \pm .8^{j} 8$ \\
\hline & & 100 & $44.3 \pm .8$ & $35.5 \pm 1.3$ & $27.8 \pm 1.2$ & $22.5 \pm 0.3$ & $17.5 \pm 1.6$ \\
\hline & \multirow[t]{2}{*}{35} & 40 & $50.3 \pm 1.3$ & $43.3 \pm 1.3$ & $33.7 \pm 1.3$ & $25.4 \pm 2.3$ & $20.7 \pm 1$ \\
\hline & & 100 & $46.7 \pm 1.8$ & $38.7 \pm .3$ & $24.3 \pm .9$ & $23.3 \pm 1.3$ & $17.2 \pm 1$ \\
\hline \multirow{4}{*}{ صِّ } & \multirow[t]{2}{*}{27} & 40 & $50.6 \pm 1.8$ & $40.4 \pm 2$ & $27.4 \pm 1.2$ & $21.9 \pm 0.7$ & $16.3 \pm 1.5$ \\
\hline & & 100 & $34.9 \pm 2.2$ & $35.1 \pm 1.5$ & $28.8 \pm 1.5$ & $25 \pm 2$ & $14.7 \pm 5.7$ \\
\hline & \multirow[t]{2}{*}{35} & 40 & $45.5 \pm 2.7$ & $39.2 \pm 1.6$ & $29.7 \pm 1.5$ & $22.3 \pm 1.5$ & $17.2 \pm 0.9$ \\
\hline & & 100 & $41 \pm 2$ & $36.5 \pm 1.3$ & $21 \pm 1$ & $17.3 \pm 2$ & $10.2 \pm 7$ \\
\hline \multirow{4}{*}{ 翟 } & \multirow[t]{2}{*}{27} & 40 & $42.9 \pm 1.5$ & $35.9 \pm .7$ & $36.3 \pm 1.1$ & $36.8 \pm 3.6$ & $20.5 \pm 1.6$ \\
\hline & & 100 & $27.9 \pm 1.8$ & $21.7 \pm .9$ & $22.1 \pm .3^{1}$ & $27 \pm 0.7$ & $12 \pm 0.9$ \\
\hline & \multirow[t]{2}{*}{35} & 40 & $20.9 \pm .5$ & $20 \pm .6$ & $12.7 \pm 2.1$ & $12.2 \pm 1.9$ & $10 \pm 0.6$ \\
\hline & & 100 & $19.3 \pm 1.3$ & $14.3 \pm 2.2$ & $7.5 \pm 1.6$ & $5 \pm 1$ & $4 \pm 0.5$ \\
\hline
\end{tabular}

$\mathrm{A}, \mathrm{b}, \mathrm{c}, \mathrm{d}, \mathrm{e}, \mathrm{f},--------$ means in the same column per each item having different letter are significantly different $(\mathrm{P}<0.01)$

The interaction of the microorganism type and temperature shows enhancement of the degradation of the pirimipos-methyl through the presence of the bacteria or fungi strain under $35^{\circ} \mathrm{C}$ The percent residue of $40 \mathrm{ppm}$ pirimipos-methyl, incubated with bacteria strain under $27^{\circ} \mathrm{C}$ ranged from $50.6 \pm 1.8$ to $16.3 \pm 1.5 \%$ after 1 and 7 days, respectively. Under $35^{\circ} \mathrm{C}$ the residue of pirimipos-methyl was $45.5 \pm 2.7$ and $17.2 \pm 9 \%$ after 1 and 7 days respectively. The percent residue of $100 \mathrm{ppm}$ pirimipos-methyl at $27^{\circ} \mathrm{C}$ was $34.9 \pm 2.2$ after the 1 day and $14.7 \pm 5.7 \%$ after 7 days. Under $35^{\circ} \mathrm{C}$ the percent residue ranged between $41 \pm 2 \%$ and $10.2 \pm 7 \%$ after the first and $7^{\text {th }}$ day respectively.

Pirimipos-methyl was degraded through the fungi strain under $35^{\circ} \mathrm{C}$ faster than under $27^{\circ} \mathrm{C}$. At the beginning of the incubation period, the biodegradation rate of pirimipos-methyl by fungi strain was faster than by bacteria strain, then tend to be slower until the $7^{\text {th }}$ day. The percent residue of pirimipos-methyl $40 \mathrm{ppm}$ under $27^{\circ} \mathrm{C}$ ranged from $42.9 \pm 1.5$ to $20.5 \pm 1.6 \%$ for the $1^{\text {st }}$ to $7^{\text {th }}$ day, respectively. In the case of $35^{\circ} \mathrm{C}$ the percent residue ranged between $20.9 \pm 5$ and $10.0 \pm 6 \%$ for the $1^{\text {st }}$ and the $7^{\text {th }}$ day. Table 6 Racke and Coats (1988a) investigated comparative degradation of six organophosphorus insecticides in soil as affected by enhanced microbial degradation. Racke et al.,(1990)studied resistance of chlorpyrifos to enhance biodegradation in soil.

The degradation rate of pirimipos-methyl was faster during the all period of experiment by the fungi than the bacteria strain under $35^{\circ} \mathrm{C}$. On the other hand degradation by bacteria was accelerated up to the fourth day of incubation (Table 6). These effects may be due to the increase of the extracellular esterase activity, which tend to increase from the second day of incubation period. Generally, the degradation of pirimipos-methyl by the tested microorganisms was higher at $35^{\circ} \mathrm{C}$ than at $27^{\circ} \mathrm{C}$ with $40 \mathrm{ppm}$ concentration. The interaction of the two tested strains and the concentrations showed that the fungi degraded the pirimipos-methyl faster than the bacteria strain under the concentration of $40 \mathrm{ppm}$ and $100 \mathrm{ppm}$. This mean that the biodegradation of pirimipos-methyl by the fungi strain depended on an enzymatic system difference from the esterase. Martinez-Toledo et al. (1992) reported that the fungal populations and denitrifying bacteria were not affected as a consequence of the addition of the organophosphorus insecticides such methylpyrimifos and chlorpyrifos to the agricultural soil, showing that these microorganisms can tolerate high amounts of those insecticides.

Fayoum J. Agric. Res. \& Dev., Vol.19, No.2, July, 2005 
Ekram F. Hashem, et al.,

1.

Table 6

Fayoum J. Agric. Res. \& Dev., Vol.19, No.2, July, 2005 


\section{REFERENCES}

Aly M. I.; M. A. Mansour and M. I. Zeid (1987): The influence of soil types on aldicarb, chlorpyrifos and methomyl persistence, Alex. J. Agric. Res. 32:419-430.

Cink J.H. and R. J. Coats (1993): Effect of concentration, temperature and and soil moisture on the degradation of chlorpyifos in an urban Iowa soil. A-C-S-Symp-Ser-Am-Chem-Sco., 522: 62-69

Ellen J.; L.R. Peterson and S.M. Finegold (1994): Diagonative Microbiology. Ninth Edition, Partt 2, Chap.14, 168-188 Mosby Stain louis USA.

Getzin L.W. (1968): Persistence of diazinon and zinophos in soil, effects of autoclaving, temperature, moisture, and acidity, J Econ. Entomol., 61: 1560 .

Getzin L.W. and I. Rosefield (1968): Persistence of diazinon and zinophos in soil, J. Econ. Entomol., 59: 512-16..

Gomori G. (1953): Human esterases,Journal of laboratory and clinical medicine, 42,446-453

Gruzdyev G.S.; V. A. Zinchennko; V.A. Kalinin and R.I. Slovtsov (1983): The chemical protection of plants. MIR Publishers. Moscow.

Laws E.A. (1992): Aquatic Pollution An Introductory Text. John Wiley \& Sons; Inc. New York, U.S.A

Lichtenstein E.P. and K.R. Schulz (1964): The effect of moisture and microorganisms on the persistence and metabolism of some organophosphorus insecticides in soil, with special emphasis on parathion.

Lowery O.H.; N.J. Rosebrough; A.L. Farr and R.J. Randall. (1952): Protein measurement with the Folin phenol reagent, J. Biol. Chem. 193: 265-275.

Martinez-Toledo M.V.; V. Salmeron and J. Gonzalez-Lopez (1992): Effect of the insecticides metylpyrimifos and chlorpyrifos on soil microflora in an agricultural loam . Plant and soil, 147:25-30.

Mulbry W.W.; P.L. Delvalle and J.S. Karns (1996): Biodegradation of the organophosphate insecticide coumaphos in highly contaminated soils and in liquid wastes. Pestic. Sci., 48: 149-155.

Naumann K. (1959): Einfluses von pflanzen schutzmittel auf die bodenmikroflora Mit. Biol. Bund. Anst. Berlin, 97: 109. (c.f. "Organophosphorus pesticides:Organic and biological chemistry" chapter III, CRC press, 1979.

Ou L.T. and A. Sharma (1989): Degradation of methyl parathion by a mixed bacterial culture and a Bacillus sp. Isolated from different soils. J. Agric. Food Chem., 37: 1514-1518.

Fayoum J. Agric. Res. \& Dev., Vol.19, No.2, July, 2005 
Ekram F. Hashem, et al.,

Racke K.D. and J.R. Coats (1988a): Comparative degradation of organophosphorus insecticides in soil specificity of enhanced microbial degradation. J. Agric. Food Chem., 36: 193-199.

Racke K.D.; D.A. Laskowski, and M.R. Schultz (1990): Resistance of chlorpyrifos to enhanced biodegradation in soil. J. Agric. Chem. 38: 1430-1436.

Swelam E.S. (1996): Movement and persistence of aldicarb and imidacloprid in two different types of soil. Master of science thesis Faculty of Agriculture Cairo University.

Walker W.W. and B.J. Stojanovic (1973): Microbial versus chemical degradation of malathion in soil. J. Environ. Qual., 2: 229-32. 